\title{
PENDIDIKAN ISLAM DALAM PERADABAN INDUSTRI FASHION
}

\author{
Ahmad Mustami \\ Ps UIN Sunan Kalijaga, Jl. Marsda Adisucipto Yogyakarta \\ e-mail: ahmadmustami@yahoo.co.id
}

\begin{abstract}
This article discusses the concept Apparel in Islamic education. Which is currently a lot of variety of fashion in dress. Although the general function of clothes is a human genitalia cover and protect the body from the heat of the sun. However hijab at this time not just cover the nakedness, but rather as a fashion style that became a common thing now is infecting the womenfolk including Muslim. Ranging from clothes, pants, until hijab began in innovation so as to attract the eye. Although it is not yet represent the shape and fashion model/standard clothes, but felt able to express Islamic education in the dressing (hijab) and a fashion model/Islamic clothing. Obviously keep on religious norms, ethical and moral teachings. Substance of clothing in Islam is polite in accordance with the values of Islamic Education.
\end{abstract}

Abstrak. Artikel ini membahas tentang konsep Pakaian dalam Pendidikan Islam. Yang mana saat ini banyak berbagai fashion dalam berpakaian. Walaupun secara umum fungsi pakaian merupakan penutup aurat manusia sekaligus melindungi badan dari panasnya matahari. Akan tetapi pakaian pada saat ini tidak hanya sekedar penutup aurat, melainkan sebagai fashion style yang menjadi hal lumrah yang sekarang ini menjangkiti para kaum hawa termasuk muslimah. Mulai dari baju, celana, sampai hijabpun mulai di inovasi sedemikian rupa agar menarik mata. Walaupun hal tersebut belum mewakili bentuk dan model busana/pakain yang baku, tetapi dirasa mampu mengungkapkan pendidikan Islam dalam berpakain (hijab) dan model busana/pakaian Islami. Tentunya tetap menjaga pada normanorma agama, etika dan ajaran moral. Subtansi dari pakaian dalam ajaran Islam adalah sopan sesuai dengan nilai-nilai Pendidikan Islam.

Kata Kunci : Pendidikan Islam, Pakaian, Fashoin, Aurat. 


\section{PENDAHULUAN}

Adanya berbagai kemajuan dan perkembangan peradaban yang serba canggih dan cepat dapat menghasilkan produk-produk yang beraneka ragam yang digunakan untuk kebutuhan manusia. Salah satu aspek yang sangat berkembang dan dapat mempengaruhi kehidupan manusia adalah industri pakaian, pakaian pada dasarnya adalah kebutuhan primer yang sangat dibutuhkan oleh manusia di dunia dan perkembangannya cukup signifikan, hal ini terbukti dengan berdirinya pabrik-pabrik pakaian dengan berbagai model dan bahan yang sangat bervariasi di seluruh dunia.

Pakaian merupakan salah satu kebutuhan pokok manusia. Dimana pakaian merupakan hal yang sangat penting sekali bagi manusia. Sementara ilmuan yang ada berpendapat bahwa manusia baru mengenal pakaian jauh sebelum manusia mengenal kebutuhan papan. ${ }^{1}$ Menurut mereka homo sapiens, nenek moyang kita berasal dari Afrika yang gerah. Sebagian mereka berpindah dari tempat yang satu ke tempat yang lainnya. Di tempat itulah dan pada saat itulah mereka mulai berpakaian yang bermula dari kulit hewan, tujuan mereka memakai pakaian kulit untuk menghangatkan kulit.

Beberapa tahun yang lalu barulah ditemukan cara menjahit kulit, dan dari sanalah pakaian semakin berkembang. Seperti yang kita ketahui masyarakat Tuareg di Gurun Sahara, Afrika Utara, menutupi seluruh tubuh mereka dengan pakaian, agar terlindungi dari panas matahari dan pasir yang biasa beterbangan di gurun terbuka. ${ }^{2}$ Disisi lain, pakaian juga berkaitan dengan rasa keindahan, juga memberi dampak psikologis bagi pemakainya. Serta pakaian juga berkaitan dengan budaya dan perkembangan masyarakat.

${ }^{1}$ M. Quraish Shihab, Jilbab Pakaian Wanita Muslimah, (Jakarta: Lentera Hati, 2004), h. 29.

Ibid., h. 31 
Islam telah memperkenalkan pula pakaian-pakaian yang seharusnya dipakai oleh kaum muslim. Terutama bagi wanita yang berjilbab. Pemakaian jilbab dalam arti pakaian yang menutup seluruh tubuh wanita kecuali wajah dan tangan yang pernah menjadi kurang perhatian masyarakat Islam sejak abad 19. Kembali marak sekitar 5 tahun terakhir ini dan kelihatannya semakin banyak peminatnya. Persoalan tersebut menjadi semakin marak dan terangkat ke nasional setelah banyak pendesain membuat beraneka ragam jenis jilbab. Para pendesain tidak hanya merancang jenis jilbab akan tetapi dikenalkan melalui modelmodel dan artis terkenal yang ditampilkan di beberapa stasiun TV. Sehingga banyak halayak yang menyaksikan dan menjadi model dalam penggunaan hijab. Apalagi sekarang bermaacam ragam variasi dalam menggunakan jilbab.

Kini busana hijab menjadi salah satu fashion yang sangat diminati oleh masyarakat dengan modelnya yang simple dan mudah digunakan, apalagi dengan merebaknya tutorial hijab dengan berbagai model, dan yang penting adalah hijab merupakan tren di zaman ini. Banyak yang berlomba-lomba untuk mempercantik diri dengan memakai hijab, bahkan sekarang banyak berdiri komunitas-komunitas hijabers yang menjadi tempat untuk berbagi cerita maupun up-date mengenai tren hijab masa kini. Munculnya komunitas hijabers yang sedang populer di masyarakat tidak hanya menjadi sekedar komunitas wanita biasa, melainkan selalu diidentikkan pada komunitas high class.

Budaya busana hijab tersebut baru-baru ini booming di Indonesia terutama di dunia modern. Dalam konteks kekinian, hijab tidak hanya menjadi simbol identitas pemeluk agama Islam akan tetapi hijab juga menjadi simbol identitas, status, dan kekuasaan seseorang. Dalam masyarakat muslim modern, hijab lebih sering diasosiasikan dengan gaya hidup kelas atas. Satu hal yang menjadi pertanyaan kita adalah bagaimana tren fashion hijab tersebut dengan cepatnya mampu memberikan perubahan 
pandangan yang signifikan dalam kehidupan sosial masyarakat dari yang sebelumnya dianggap hanya sebagai simbol/identitas suatu agama menjadi sebuah budaya yang identik dengan modernitas. Kita perlu tahu mengapa bisa terjadi pergeseran fungsi hijab pada zaman dahulu dan sekarang yang mengubah stereotype hijab itu sendiri secara simbolis.

Banyak analisis tentang faktor-faktor yang mendukung tersebarnya fenomena berjilbab di kalangan kaum muslimat salah satu faktor yang juga diduga sebagai pendorong maraknya pemakaian jilbab adalah faktor ekonomi. Bisa jadi juga maraknya berjilbab itu adalah sebagai sikap penentangan terhadap dunia Barat yang sering kali menggunakan standar ganda sambil melecehkan umat Islam dan agamanya, ada juga yang menduga bahwa pemakaian jilbab adalah simbol pandangan politik yang pada mulanya diwajibkan oleh kelompok-kelompok Islam dengan wanita-wanita muslimah yang lain atau yang non muslim. ${ }^{3}$

Sebagai seorang muslim kita harus melihat kaidah-kaidah berbusana yang sesuai dengan syari'at Islam, supaya apa yang kita kenakan dapat dipertanggungjawabkan di akhirat kelak dan tidak memicu hal-hal yang tidak diinginkan. Berbeda dengan zaman sekarang banyak sekali model yang tidak sesuai dengan syari'at Islam, sebagai contoh ada model pakaian yang dikenal dengan istilah 'you can see' yang artinya kamu boleh melihat, atau bahkan ada yang rela mati-matian untuk menaikkan bagian bawahnya keatas dan yang atas rela untuk diturunkan ke bawah, atau ada yang mengenakan baju yang semestinya dipakai oleh anak TK/SD (pakaian super ketat) hingga terlihatlah apa yang seharusnya tidak boleh dilihat. Nauzubillah min dzalik.

Dari permasalahan di atas, penulis akan mengkaji lebih jauh tentang pakaian perempuan dalam Alquran. Bagaimana ketentuan berpakaian perempuan itu sebenarnya dan bagaimana implementasi dalam dunia pendidikan Islam. Dalam hal ini penulis

${ }^{3}$ Ibid., h. 1-2 
akan menggunakan pendekatan tematik terhadap ayat-ayat yang berkenaan dengan pakaian.

\section{PAKAIAN DALAM PANDANGAN ALQURAN}

Pakaian menurut bahasa adalah segala sesuatu yang menempel pada tubuh dari ujung rambut sampai ujung kaki. Sedangkan menurut istilah adalah sesuatu yang kita kenakan setiap hari dari ujung rambut sampai ujung kaki beserta segala perlengkapannya, seperti tas, sepatu, dan segala macam perhiasan yang melekat padanya.

Pengertian pakaian (jilbab) dalam Lisanul Arab adalah Jilbab berarti selendang, atau pakaian lebar yang dipakai wanita untuk menutupi kepala, dada dan bagian belakang tubuhnya. ${ }^{4}$ Sedangkan dalam Al-Mu'jam al-Wasit adalah Jilbab berarti pakaian yang dalam (gamis) atau selendang (khimār), atau pakaian untuk melapisi segenap pakaian wanita bagian luar untuk menutupi semua tubuh seperti halnya mantel. Dan dalam Mukhtār Shihāh adalah Jilbab berasal dari jalaba, artinya menarik atau menghimpun, sedangkan jilbab berarti pakaian lebar seperti mantel. Pakaian (sandang) adalah salah satu kebutuhan pokok manusia di samping makanan (pangan) dan tempat tinggal (papan). ${ }^{5}$

Sehinggga dapat ditarik kesimpulan bahwa pakaian (jilbab) dapat diartikan antara lain, baju yang longgar atau kerudung penutup kerudung wanita, atau pakaian yang menutupi baju dan kerudung yang dipakainya, atau semua yang dipakainya, atau semua pakaian yang menutupi badan wanita.

Alquran paling tidak menggunakan tiga istilah untuk pakaian, yaitu libās, śiyāb, dan sarābīl.

${ }^{4} I b n u$ Manẓūr, Lisān al-'Arab, (Beirut: Dār Șādir, t.th.), cet I, Jil. I, h. 272

${ }^{5} \mathrm{http}$ ://www.muslimberjilbab.blogspot.com/2005/03/busana-muslimidentitas-dirimuslimah.html. diakses 15 april 2015. 


\section{Libās}

Kata libās di dalam Alquran, pada mulanya berarti penutup, apapun yang ditutup. Fungsi pakaian sebagai penutup amat jelas. Tetapi, perlu dicatat bahwa ini tidak harus berarti "menutup aurat", karena cincin yang menutup sebagian jari juga disebut libās. Memang, kita boleh berkata bahwa yang menutup seluruh badannya kecuali wajah dan (telapak) tangannya, menjalankan bunyi teks ayat, bahkan mungkin berlebih. Namun dalam saat yang sama kita tidak wajar menyatakan terhadap mereka yang tidak memakai kerudung, atau yang menampakkan tangannya, bahwa mereka "secara pasti telah melanggar petunjuk agama." Bukankah Alquran tidak menyebut batas aurat? Para ulama pun ketika membahasnya berbeda pendapat. $^{6}$

Ketika berbicara tentang laut, Alquran surat al-Nahl ayat 14 menyatakan bahwa:

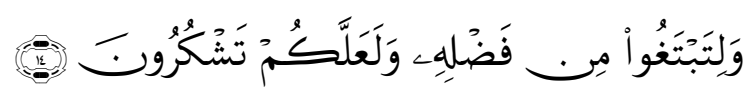

Dan kamu mengeluarkan dari laut itu perhiasan (antara lain mutiara) yang kamu pakai" (Q.S Nahl:14).

Kata libās digunakan dalam Alquran untuk menunjukkan pakaian lahir maupun batin.

\section{Siyāb}

Kata ini di dalam Alquran. Digunakan untuk menunjukkan pakaian lahir. Kata ini diambil dari kata șaub yang berarti kembali, yakni kembalinya sesuatu pada keadaan semula, atau pada keadaan yang seharusnya sesuai dengan ide pertamanya. Ungkapan yang menyatakan, bahwa "awalnya adalah ide dan akhirnya adalah kenyataan". Ungkapan ini berarti kenyataan

${ }^{6}$ M. Qurish Shihab, Jilbab Pakaian Wanita Muslimah, Pandangan Ulama' Masa Lalu dan Cendekiawan Kontemporer, (Jakarta : Lentera Hati, 2006,) h. 188189 
harus dikembalikan kepada ide asal, karena kenyataan adalah cerminan dari ide asal.

Al-Rāghib al-Isfahānī, seorang pakar bahasa Alquran, menyatakan bahwa pakaian dinamai siyāb atau șaub, karena ide dasar adanya bahan-bahan pakaian adalah agar dipakai. Jika bahan-bahan tersebut setelah dipintal kemudian menjadi pakaian, maka pada hakikatnya ia telah kembali pada ide dasar keberadannya. Seperti dalam Q.S. al-A'raf (7): 209 yang menjelaskan peristiwa ketika Adam dan Hawa berada di surga :

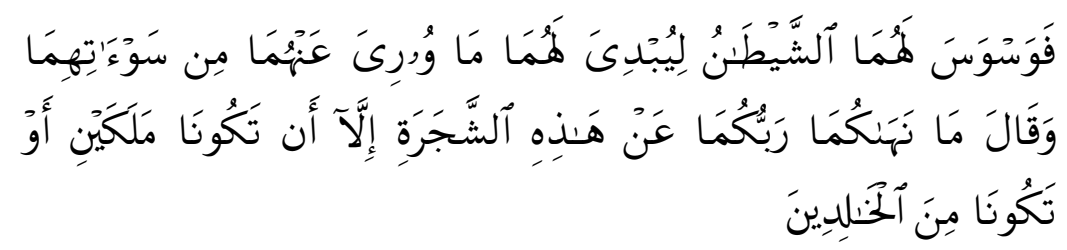

Setan membisikkan pikiran jahat kepada keduanya untuk menampilkan pada keduanya apa yang tertutup dari mereka, yaitu auratnya, dan setan berkata,"Tuhan kamu melarang kamu mendekati pohon ini, supaya kamu berdua tidak menjadi malaikat atau tidak menjadi orangorang yang kekal (disurga)".

Selanjutnya dijelaskan juga dalam Q.S. al-A'raf (7): 2 :

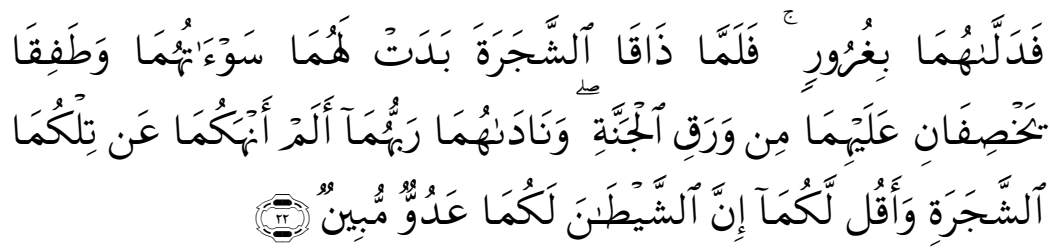

Setelah mereka merasakan (buah) pohon (terlarang) itu, tampaklah bagi keduanya aurat-auratnya, dan mulailah keduanya menutupinya dengan daun-daun surga...

Dari ayat diatas terlihat jelas bahwa ide dasar yang terdapat dalam diri manusia adalah "tertutupnya aurat", namun karena godaan setan, aurat manusis terbuka. Dengan demikian, aurat yang ditutup dengan pakaian akan dikembalikan pada ide dasarnya wajar jika pakaian dinamai șaub atau śiyāb yang berarti 
"sesuatu yang mengembalikan aurat kepada ide dasarnya", yaitu tertutup. Bahwa ide-ide membuka aurat" adalah ide setan.

\section{Sarābīl}

Kamus-kamus bahasa mengartikan kata ini sebagai pakaian, apapun jenis bahannya. Kata sarābīl bisa diartikan sebagai fungsi pakaian untuk melindungi diri dari panas, dingin dan bahaya dalam peperangan. Hanya dua ayat yang menggunakan kata tersebut, yaitu dalam surah al-Nahl ayat 81 yang diartikan sebagai pakaian yang berfungsi menangkal sengatan panas, dingin, dan bahaya peperangan. Kemudian dalam surat Ibrahim ayat 50, tentang siksa yang akan dialami orang-orang berdosa kelak di hari kemudian: pakaian mereka dari pelangkin. ${ }^{7}$ Adapun syaratsyarat pakaian Muslimah yaitu sebagai berikut yang dikutip dari buku Jilbab al-Mar'ah al-Muslimah fī al-Kitāb wa al-Sunnah (syaikh al-Albānī).

\section{Menutupi seluruh tubuh selain yang dikecualikan syariat}

Ini terdapat dalam Q.S. al-Nūr (24): 31, Allah berfirman:

"Katakanlah kepada wanita yang beriman: hendaklah mereka menahan pandangan mereka dan memelihara kemaluan mereka dan janganlah mereka menampakkan perhiasan mereka kecuali yang (biasa) nampak dari mereka. Dan hendaklah mereka menutupkan kain kudung ke dada mereka, dan janganlah menampakkan perhiasan mereka".

Menutup wajah dan dua telapak tangan tidaklah wajib bagi wanita, bahkan tidak ada larangan untuk menampakkan perhiasan yang terdapat pada wajah dan dua telapak tangan yang memang sudah biasa dikenal, seperti celak dan kutek yang tidak pernah lepas dari wanita. ${ }^{8}$

${ }^{7}$ M. Quraish Shihab, Wawasan Al-Qur'an: Tafsir Tematik atas Pelbagai Persoalan Umat, (Bandung: Mizan, Cet.XI, 2009) h. 155 - 157. Lihat juga. M. Quraish Shihab, Membumikan al-Qur'an, (Cet.1; Bandung: Mizan, 2007), h. 205 207.

${ }^{8}$ Murtadha Muthahari, Wanita dan Hijab, (Terj. Oleh Nashib Musthafa), (Jakarta: Lentera Basritama, 2002), h. 68. 
Juga firman Allah dalam Q.S. al-Aḥzāb (33): 59 yang berbunyi:

"Hai Nabi katakanlah kepada istri-istrimu, anak-anak perempuanmu dan istri -istri orang mu'min: Hendaklah mereka mengulurkan jilbabnya ke seluruh tubuh mereka. "Ayat ini menjelaskan pada kita bahwa menutup seluruh tubuh adalah kewajiban setiap wanita muslimah (mukminah) dan merupakan tanda keimanan mereka. Menutup aurat adalah salah satu dari kewajiban yang telah ditetapkan bagi muslimah, sedangkan menuntut ilmu adalah kewajiban lain yang berlaku untuk seumur hidup".

M. Quraish Shihab memiliki pandangan yang berbeda dalam menafsirkan ayat di atas, dengan manyatakan bahwa Allah swt. tidak memerintahkan muslimah memakai jilbab. Pendapatnya tersebut ialah sebagai berikut: Ayat di atas tidak memerintahkan wanita muslimah memakai jilbab, karena pada zaman itu sebagian mereka telah memakainya, hanya saja cara memakainya belum sesuai dengan apa yang dikehendaki ayat di atas. Kesan ini diperoleh dari redaksi ayat di atas yang menyatakan jilbab mereka dan yang diperintahkan adalah "Hendaklah mereka mengulurkannya." Nah, terhadap mereka yang telah memakai jilbab, tentu lebih-lebih lagi yang belum memakainya, Allah berfirman: "Hendaklah mereka mengulurkan jilbabnya."

\section{Bukan berfungsi sebagai perhiasan}

Nur Syam menjelaskan bahwa gaya berpakaian Islami pun telah memasuki paradoks globalisasi. Di satu sisi ingin seseorang ingin menampilkan gaya berpakaian Islam dengan jilbab sebagai tutup kepala, tetapi di sisi lain penonjolan ekspresi tubuh juga tetap kentara dalam hal ini keindahan oleh kasat mata. Jilbab modis yang kontemporer telah menjadi trend yang

${ }^{9}$ M. Quraish Shihab, Tafsir Al-Mishbah, Pesan, Kesan dan Keserasian AlQuran, vol. 11, (Cet ke-1; Jakarta: Lentera Hati, 2003), h. 321. 
digemari kalangan perempuan hakikatnya menjadi contoh bekerjanya sistem global paradoks yang sangat menonjol. ${ }^{10}$

Ini berdasarkan firman Allah dalam Q.S. al-Nūr (24): 31 yang berbunyi :

"Dan janganlah kaum wanita itu menampakkan perhiasan mereka".

Secara umum kandungan ayat ini juga mencakup pakaian biasa jika dihiasi dengan sesuatu, yang menyebabkan kaum lakilaki melirikkan pandangan kepadanya. Hal ini dikuatkan firman Allah dalam Q.S. al-Aḥzāb (33): 33:

"Dan hendaklah kamu tetap di rumahmu dan janganlah kamu berhias dan bertingkah laku seperti orang-orang jahiliyah".

\section{Tidak tembus pandang}

Dalam sebuah hadis Rasulullah telah bersabda:"Pada akhir umatku nanti akan ada wanita-wanita yang berpakaian namun (hakekatnya) telanjang. Diatas kepala mereka seperti terdapat bongkol (punuk) unta. Kutuklah mereka karena sebenarnya mereka adalah kaum wanita yang terkutuk." Di dalam hadis lain terdapat tambahan:

"Mereka tidak akan masuk surga dan juga tidak akan mencium baunya surga itu dapat dicium dari perjalanan sekian dan sekian". (HR.Muslim dari riwayat Abu Hurarirah).

\section{Tidak ketat hingga memperlihatkan lekuk tubuh.}

Usamah bin Zaid pernah berkata: Rasulullah pernah memberiku baju Quthbiyah yang tebal yang merupakan baju yang dihadiahkan oleh Dihyah al-Kalbi kepada beliau. Baju itupun akau pakaikan pada istriku. Nabi bertanya kepadaku:

"Mengapa kamu tidak mengenakan baju Quthbiyah?" Aku menjawab:

"Aku pakaikan baju itu pada istriku".

Nabi lalu bersabda:

${ }^{10}$ Nur Syam, Bukan Dunia Berbeda Sosiologi Komunitas Islam, (Surabaya: Pustaka Eureka 2005), h. 59 
"Perintahkan ia agar mengenakan baju dalam di balik Quthbiyah itu, karena saya khawatir baju itu masih bisa menggambarkan bentuk tulangnya". (HR. Ahmad dan Al-Baihaqi dengan sanad Hasan).

\section{Tidak menyerupai pakaian laki-laki dalam artian identitas}

Identitas seseorang bahwa pada dasarnya setiap orang memiliki keinginan di dalam dirinya untuk menentukan identitas dirinya bukan kepasrahan untuk menerima identitas diri karena ada yang mendominasi atau berkuasa. Subjek yang sebelumnya memiliki identitas yang stabil dan menyatu selanjutnya akan terfragmentasi tidak hanya menjadi satu melainkan beberapa identitas; yang terkadang hal demikian menimbulkan kontradiksi atau identitas. Menurut Goffman dalam Nasrullah bahwa setiap aktivitas seseorang melibatkan orang lainnya. ${ }^{11}$

Dari Abu Hurairah berkata: "Rasulullah melaknat pria yang memakai pakaian wanita dan wanita yang memakai pakaian pria". Dari Abdullah bin Amru yang berkata: "Saya mendengar Rasulullah bersabda: "Tidak termasuk golongan kami para wanita yang menyerupakan diri dengan kaum pria dan kaum pria yang menyerupakan diri dengan kaum wanita". Dari Abdullah bin Umar yang berkata: "Rasulullah bersabda: "Tiga golongan yang tidak akan masuk surga dan Allah tidak akan memandang mereka pada hari kiamat; orang yang durhaka kepada orang tuanya, wanita bertingkah kelaki-lakian dan menyerupakan diri dengan laki-laki dan dayyūs (orang yang tidak memiliki rasa cemburu)".

Dalam hadis-hadis ini terkandung petunjuk yang jelas mengenai diharamkannya tindakan wanita menyerupai kaum pria, begitu pula sebaliknya. Tidak menyerupai pakaian pria disini, misalnya seorang muslimah memakai celana panjang yang layaknya dipakai oleh seorang laki-laki, memakai kemeja laki-laki dll. Sehingga secara psikologis terpengaruh pada pribadi pemakainya, misalnya merasa sekuat pria, merasa tomboy dll.

\footnotetext{
${ }^{11}$ Nasrullah, R. Komunikasi Antarbudaya di Era Budaya Siber, (Jakarta: Kencana Prenada Grup Media 2012), h. 113
} 


\section{Memakai busana bukan untuk mencari popularitas}

Setiap pakaian yang dipakai dengan tujuan untuk meraih popularitas di tengah-tengah orang banyak, baik pakaian tesebut mahal, yang dipakia oleh seorang untuk berbangga dengan dunia dan perhiasannya, maupun pakaian yang bernilai rendah, yang dipakai oleh seorang untuk menampakkan kesuhudannya dan dengan tujuan riya. Ibnul Atsir berkata : "Syuhrah artinya terlihatnya sesuatu. Maksud dari Libas syuhrah adalah pakaiannya terkenal di kalangan orang-orang yang mengangkat pandangannya mereka kepadanya. Ia berbangga terhadap orang lain dengan sikap angkuh dan sombong". ${ }^{12}$

\section{NILAI-NILAI PENDIDIKAN ISLAM YANG TERKANDUNG DALAM PAKAIAN}

\section{Pakaian sebagai Penutup Aurat.}

Kata 'aurat, yang terambil dari kata 'ar yang berarti onar, aib, tercela. Keburukan yang dimaksud tidak harus dalam arti sesuatu yang pada dirinya buruk, tetapi bisa juga karena adanya faktor lain yang mengakibatkan buruk. Tidak satupun dari bagian tubuh yang buruk karena semuanya baik dan bermanfaattermasuk aurat. Tetapi bila dilihat orang, maka "keterlihatan" itulah yang buruk.

Tentu saja banyak hal yang sifatnya buruk, masing-masing orang dapat menilai. Agama pun memberi petunjuk tentang apa yang dianggapnya 'aurat atau sau'āt. Dalam fungsinya sebagai penutup, tentunya pakaian dapat menutupi segala yang enggan diperlihatkan oleh pemakai, sekalipun seluruh badannya. Tetapi dalam konteks pembicaraan tuntunan atau hukum agama, aurat dipahami sebagai anggota badan tertentu yang tidak boleh dilihat kecuali oleh orang-orang tertentu.

${ }^{12}$ http://muslimahberjilbab.blogspot.com.diakses tanggal 15 April 2015. 


\section{Pakaian sebagai Perlindungan (Takwa)}

Di sisi lain, pakaian memberi pengaruh psikologis bagi pemakainya. Itu sebabanya sekian banyak negara mengubah pakaian militernya, setelah mengalami kekalahan militer. Bahkan Kemal Ataturk di Turki, melarang pemakaian tarbūsy (sejenis tutup kepala bagi pria), dan memerintahkan untuk menggantinya dengan topi ala Barat, karena tarbūsy dianggapnya mempengaruhi sikap bangsanya serta merupakan lambang keterbelakangan.

Dalam kehidupan sehari-hari kita dapat merasakan pengaruh psikologis dari pakaian jika kita ke pesta. Apabila mengenakan pakaian buruk, atau tidak sesuai dengan situasi, maka pemakainya akan merasa rikuh, atau bahkan kehilangan kepercayaan diri, sebaliknya pun demikian. Kaum sufi, sengaja memakai shüf (kain wol) yang kasar agar dapat menghasilkan pengaruh positif dalam jiwa mereka. Memang, harus diakui bahwa pakaian tidak menciptakan santri, tetapi dia dapat mendorong pemakainya untuk berperilaku seperti santri atau sebaliknya menjadi setan, tergantung dari cara dan model pakaiannya. Pakaian terhormat, mengundang seseorang untuk berperilaku serta mendatangi tempat-tempat terhormat, sekaligus mencegahnya ke tempat-temppat yang tidak senonoh. Ini salah satu yang dimaksud Alquran dengan memerintahkan wanita-wanita memakai jilbab. Yang demikian itu agar mereka lebih mudah untuk dikenal (sebgai Muslimah/wanita terhormat) sehingga mereka tidak diganggu.

Fungsi perlindungan bagi pakaian dapat juga diangkat untuk pakaian ruhani, libās al-taqwā. Setiap orang dituntut untuk merajut sendiri pakaian ini. Benang atau serat-seratnya adalah tobat, sabar, syukur, qana'ah, ridha, dan sebagainya. 


\section{Pakaian sebagai Penunjuk identitas}

Identitas atau kepribadian sesuatu adalah yang menggambarkan eksistensinya sekaligus membedakan dari yang lain. Eksistensi atau keberadaan seseorang ada yang bersifat material dan ada juga yang imaterial (ruhani). Hal-hal yang bersifat material antara lain tergambar dalam pakaian yang dikenakannya.

Anda dapat mengetahui sekaligus membedakan murid SD dan SMP, atau Angkatan Laut dan Angkatan Darat, atau Kopral dan Jenderal dengan melihat apa yang dipakainya. Tidak dapat disangkal lagi bahwa pakaian antara lain berfungsi menunjukkan identitas serta membedakan seseorang dari lainnya. Bahkan tidak jarang ia membedakan status sosial seseorang.

Rasulullah saw. amat menekankan pentingnya penampilan identitas muslim, antara lain melalui pakaian.

Rasulullah saw, melarang lelaki yang memakai pakaian perempuan dan perempuan memakai pakaian lelaki (HR. Abu Daud).

Kepribadian umat juga harus ada. Ketika Rasul membicarakan bagaimana cara yang paling tepat untuk menyampaikan/mengundang kaum Muslim melaksanakan shalat, maka ada diantara sahabatnya yang mengusulkan menancapkan tanda, sehingga yang melihatnya segera datang. Beliau tidak setuju. Ada lagi yang mengusulkan untuk menggunakan terompet, dan komentar beliau: "Itu cara Yahudi". Ada juga yang mengusulkan menyembunyikan lonceng. "Itu cara Nasrani", sabda beliau. Akhirnya yang disetujui beliau adalah adzan yang kita kenal sekarang.

Kepribadian imaterial (ruhani) bahkan ditekankan oleh Alquran, antara lain melalui Q.S. al-Hadīd (57): 16 : 


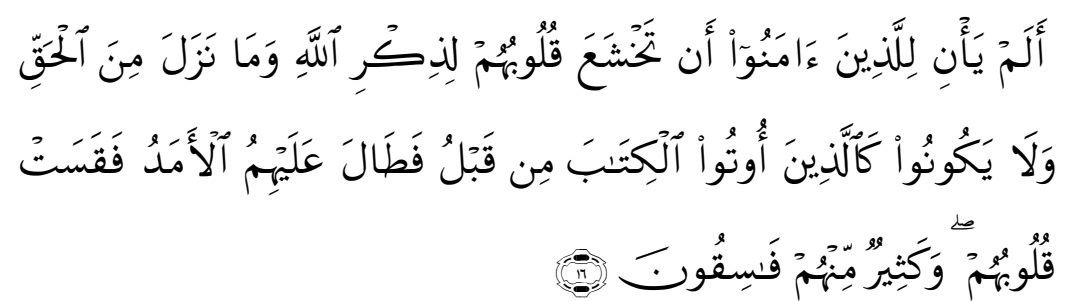

Belumkah datang waktunya bagi orang-orang yang beriman, untuk tunduk hati mereka mengingat Allah dan kepada kebenaran yang telah turun, dan janganlah mereka seperti orang-orang sebelumnya yang telah diberikan Al-Kitab (orang Yahudi dan Nasrani). Berlalulah masa yang panjang bagi mereka sehingga nanti mereka menjadi keras. Kebanyakan diantara mereka adalah orang-orang fasik.

Seorang Muslim diharapkan mengenakan pakaian ruhani dan jasmani yang menggambarkan identitasnya. Disadari sepenuhnya bahwa Islam tidak datang menentukan mode pakaian tertentu, sehingga setiap masyarakat dan periode, bisa saja menentukan mode yang sesuai dengan seleranya. Namun, demikian agaknya tidak berlebihan jika diharapkan agar dalam berpakaian tercermin pula identitas itu. Tidak diragukan lagi bahwa jilbab bagi wanita adalah gambaran identitas seorang Muslimah. ${ }^{13}$

\section{Pakaian sebagai Penunjuk Kepribadian Seseorang.}

Setiap orang mempunyai pribadi masing-masing sesuai ciriciri pribadi yang mereka miliki. Ciri-ciri inilah yang membedakan seseorang dengan yang lainnya. Kepribadian sebenarnya adalah suatu masalah yang abstrak, hanya dapat dilihat lewat penampilan, tindakan, ucapan, cara berpakaian, dan dalam menghadapi setiap persoalan. Kepribadian yang sesungguhnya adalah abstrak (ma'nawi), sukar dilihat atau diketahui secara nyata, yang dapat diketahui adalah penampilan atau bekasnya dalam segala segi dan aspek kehidupan. Misalnya dalam tindakannya, ucapan, cara bergaul, berpakaian, dan dalam

${ }^{13}$ Shihab, Wawasan..., h. 162-170. Lihat juga Shihab, Membumikan..., h. 212-220. 
menghadapi setiap persoalan atau masalah, baik yang ringan maupun yang berat.

Kepribadian adalah keseluruhan dari individu yang terdiri dari unsur fsikis dan fisik. Dalam makna demikian, seluruh sikap dan perbuatan seseorang merupakan suatu gambaran dari kepribadian orang itu, asal dilakukan secara sadar. Dan perbuatan yang baik sering dikatakan bahwa orang itu tidak mempunyai kepribadian yang baik atau mempunyai akhlak yang tidak mulia. Oleh karena itu, masalah kepribadian adalah suatu hal yang sangat menentukan tinggi rendahnya kewibawaan seorang guru dalam pandangan anak didik atau masyarakat. Dengan kata lain, baik tidaknya citra seseorang ditentukan oleh kepribadian. Lebih lagi bagi seorang guru, masalah kepribadian merupakan faktor yang menentukan terhadap keberhasilan melaksanakan tugas sebagai pendidik. Kepribadian dapat menentukan apakah guru menjadi pendidik dan pembina yang baik ataukah akan menjadi perusak atau penghancur bagi hari depan anak didik, terutama bagi anak didik yang masih kecil (tingkat sekolah dasar) dan mereka yang sedang mengalami kegoncangan jiwa (tingkat remaja).

Kepribadian adalah unsur yang menentukan keakraban hubungan guru denan anak didik. Kepribadian guru akan tercermin dalam sikap dan perbuatannya dalam membina dan membimbing anak didik. Jadi, tidak seorang pun yang dapat menjadi seorang guru yang sejati (mulia) kecuali bila dia menjadikan dirinya sebagai bagian dari anak didik yang berusaha untuk memahami tentang kselitan anak didik dalam hal belajar dan keselitan lainnya di luar masalah belajar, yang bisa menghambat aktivitas belajar anak didik, maka guru tersebut akan disenangi anak didiknya.

Sebagai teladan, guru harus memiliki kepribadian yang dapat dijadikan profil dan idola, seluruh kehidupannya adalah figur yang paripurna. Itulah kesan terhadap guru sebagai sosok 
yang ideal. Dari Sedikit saja guru berbuat yang tidak atau kurang baik, akan mengurangi kewibawaannya dan kharisma pun secara perlahan lebur dari jati diri. Karena itu, kepribadian adalah masalah yang sangat sensitif sekali. Penyatuan kata dan perbuatan yang dituntut dari guru, bukan lain perkataan dengan perbuatan, ibarat kata pepatah, pepat di luar runcing di dalam.

Guru adalah mitra anak didik dalam kebaikan. Guru yang baik, anak didik pun menjadi baik. Tidak ada seorang guru yang bermaksud menjerumuskan anak didiknya ke lembah kenistaan. Karena kemuliaan guru, berbagai gelar pu disandangnya. Guru adalah pahlawan tanpa pamrih, pahlawan tanpa tanda jasa, pahlawan ilmu, pahlawan kebaikan, pahlawan pendidikan, makhluk serba bisa, atau dengan julukan yang lain seperti interpreter, artis, kawan, warga negara yang baik, pembangun manusia, pembawa kultur, pioner, reformer dan terpercaya, soko guru, bhatara guru, ki ajar, sang guru. ${ }^{14}$

\section{PENUTUP}

Dari penjelasan diatas, dapat disimpulkan bahwa pakaian merupakan kebutuhan pokok manusia yang kita kenakan setiap hari dari ujung kaki beserta segala perlengkapannya. Dalam artikel ini penulis menggunakan metode tematik. Di dalam Alquran ada tiga istilah yang digunakan untuk pakaian yaitu :Libās, adalah penunjuk pakaian lahir maupun batin. śiyāb, adalah untuk menunjukkan pakaian lahir. Sarābīl. Adalah pakaian yang fungsinya melindungi panas, dingin dan peperangan.

Adapun nilai-nilai pendidikan yang terkandung dalam pakaian yaitu : Pakaian sebagai penutup aurat, Pakaian sebagai pelindung (taqwa). Pakaian sebagai penunjuk identitas. Pakaian sebagai petunjuk kepribadian seseorang terutama seorang guru. Sebagai seorang muslim kita harus melihat kaidah-kaidah

${ }^{14}$ Syaiful Bahri Djamah, Guru dan Anak Didik: Dalam Interaksi Edukatif, (Jakarta: Rineka Cipta, 2005), h. 39-41. 
berbusana yang sesuai dengan syari'at Islam. Supaya apa yang dipakai mencerminkan seorang muslim yang berkepribadian Islam.

\section{DAFTAR PUSTAKA}

Djamarah, Syaiful Bahri, Guru dan Anak Didik: Dalam Interaksi Edukatif, Jakarta: Rineka Cipta, 2005.

Shihab, M. Quraish, Jilbab Pakaian Wanita Muslimah, Pandangan Ulama' Masa Lalu Dan Cendekiawan Kontemporer, Jakarta: Lentera Hati, 2006.

Shihab, M. Quraish, Tafsir Al-Mishbah, Pesan, Kesan dan Keserasian Al-Quran, vol. 11, cet I; Jakarta: Lentera Hati, 2003.

Shihab, M. Quraish, Jilbab Pakaian Wanita Muslimah, Jakarta: Lentera hati, 2004.

Shihab, M. Quraish, Wawasan Alquran: Tafsir Tematik atas pelbagai persolaan Umat, Bandung: Mizan, Cet.XI, 2000.

Mandzur, Ibnu, Lisanul Arab, Jilid I, cet. I; Beirut: Dār Shadir, t.th,

Muthahhari, Murtadha Wanita dan Hijab Terj. Oleh Nashib Musthafa, Jakarta: Lentera Basritama, 2002.

Nasrullah, R. Komunikasi Antarbudaya di Era Budaya Siber, Jakarta: Kencana Prenada Grup Media 2012.

Syam, Nur, Bukan Dunia Berbeda Sosiologi Komunitas Islam, Surabaya: Pustaka Eureka 2005.

http: //Muslimahberjilbab. blogspot. com/ 2015/ 04/ busanamuslim-identitas diri/ mulimah.

Shihab, M. Quraish, Membumikan Alquran, Bandung: Mizan, Cet.1, 2007. 